Island Studies Journal, Vol. 1, No. 1, 2006, pp. 43-54

\title{
Islandness or Smallness? A Comparative Look at Political Institutions in Small Island States
}

\author{
Dag Anckar
}

Department of Political Science

Åbo Akademi University

Finland

dag.anckar@abo.fi

\begin{abstract}
In order to explicate the relevance of the island dimension for political categories, for each of seven political institutions, a series of four comparisons are conducted on a global basis. The first is between small island states and all other states, the second is between small island states and larger island states, the third is between small island states and small mainland states, and the fourth is between island states and mainland states, regardless of size. The finding is that islandness links in many instances to the choice of institutional settings. Political scientists are therefore well-advised to include in their analyses islandness among the factors that shape institutional choices.
\end{abstract}

Key-words: Comparative politics, islandness, island studies, political institutions, small island states, state size.

Copyright @ 2006. Institute of Island Studies, University of Prince Edward Island, Canada.

\section{Introduction}

Island researchers tend to maintain somewhat different interpretations of the nature of the island dimension. Whereas some see islands not as essentially different, but merely more extreme, and conveniently replicated versions of what is found in the continental world of geographical study (Bayliss-Smith et al., 1988: 284), others tend to emphasize what is special about islands and how their experience differs qualitatively from that of mainland states (e.g. Newitt, 1992: 16). Assuredly, there is a lot to be said for a general and independent impact of the island factor. For one thing, the concept of islands has informed literary, artistic, scientific and popular culture in a variety of ways (Royle, 2001: 11-22). Examples from social and political life suggest that due to isolation and historical legacies, many small island societies display a consonance with aspects of traditional politics and a rejection of aspects of modern politics (e.g. Ghai, 1988: 39-46; Larmour, 1994: 8; Lawson, 1996), and it is suggested in the literature that a combination of smallness and islandness accounts for a special kind of political and economic resourcefulness and also for a potential for rapid policy deployment (e.g. Baldacchino, 2000; 2002). However, these and other examples notwithstanding, it may still be the case that the impact of the island dimension is context-dependent, and this article investigates if the political institution context represents susceptibility or depreciation in regard to the island category. 
The exposition embarks from a quite specific political-science frame of reference. In his study from 1992 on Democracy and Development, Axel Hadenius made the observation that popular government apparently flourishes best in small states and that the real micro-states, with a population of less than 100,000, have surprisingly high values for democracy. Hadenius introduced in his analysis the idea that island states, as they are usually small, may be of special interest in this regard, and his subsequent analysis of the impact of the island factor indeed suggested that rather than small-sized states, island states are special (Hadenius, 1992: 122-126). When controlling for spuriousness, however, Hadenius came up with the conclusion that island states are far more Protestant dominated than others, and that this feature weakens much the connection between islandness and democracy. His conclusion, therefore, was "that the often very small island states are not, as such, as special as they appear to be on simple inspection of the political geography” (1992: 127). The conclusion that Protestantism emerges in this connection as a key factor may indeed be seriously challenged (Anckar \& Anckar, 1995: 213-216); however, this article does not pursue further this particular line of reasoning. Instead, the article takes its

point of departure in the methodological issue raised by Hadenius that is about the impact of smallness versus the impact of islandness. Indeed, islands and island groups make up the great majority of the world's small states (Lowenthal, 1992: 18-19); therefore, if island states are special in terms of politics, is this because they are islands or is it because most island states are small?

It needs to be emphasized that this exercise does not constitute an effort to explain why microstates, when compared to other states or when compared to each other, have installed the one or the other institution or institutional device. Although island civil societies are certainly likely to develop specific features that may have spill-over effects for the shaping of political institutions, these effects remain outside the scope of this article. The exercise also leaves out of consideration a whole set of factors and circumstances that stand out as usual suspects in attempts to understand politico-institutional variation; among these factors are ethnic homogeneity or heterogeneity, colonial legacies, level of modernization, and the like. The ambition of this effort is not in the direction of finding out to what extent islandness manages the competition from these and other contesting variables. The ambition is one and only: to grasp, evaluate and compare the impact on institution-building of the two factors size and islandness, the ultimate goal being to encircle the significance of islandness. In terms of causation the ambition therefore does not stretch beyond a minimal definition, according to which causes refer to events or conditions that raise the probability of an outcome occurring (Gerring, 2005: 169).

\section{The Comparative Strategy}

Given the aforementioned aim, relevant comparisons shall confront island states and other states while controlling for size, and shall in like manner confront differences in size while controlling for islandness. The logic may be explained by reference to Table 1 , that is based on a crossing of two dichotomized dimensions, whether states are islands or not and whether states are small or not. The table, then, has four cells, one for small island states, one for small non-island states, one for larger island states, and one for larger non-island states. Let us suppose that we are interested in finding out to what extent islandness and smallness connect to a certain feature (F), be that democracy, economic productivity, a certain level of social capital, or the like. For the sake of 
simplicity, let us further suppose that there are in each cell 50 states. In the table, three imaginary distributions (A, B, C) are inserted, that report for each cell the amount of states that have the feature in question. Obviously, a type A distribution would strongly suggest that islandness makes a difference whereas size does not: F relates to islandness be the island states small or large, but relates much weaker to size. In contrast, a type B distribution suggests an impact of size but not of islandness: $\mathrm{F}$ is present to a larger extent in small states than in larger states, and the island dimension is clearly subordinated. Finally, a type C distribution suggests, if anything, that both islandness and size lack explanatory power in so far as these conditions apparently do not produce F to any noteworthy extent.

\section{Table 1: Comparing the Impact of Islandness and Size. A Table with 3 Imaginary Distributions}

\begin{tabular}{|l|l|l|}
\hline & Island States & Other States \\
\hline Small-Sized States & $\mathrm{A}=40$ & $\mathrm{~A}=21$ \\
& $\mathrm{~B}=43$ & $\mathrm{~B}=45$ \\
& $\mathrm{C}=10$ & $\mathrm{C}=12$ \\
\hline \multicolumn{2}{|l}{} \\
\hline Other States & $\mathrm{A}=42$ & $\mathrm{~A}=15$ \\
& $\mathrm{~B}=17$ & $\mathrm{~B}=17$ \\
& $\mathrm{C}=8$ & $\mathrm{C}=10$ \\
\hline
\end{tabular}

In the following sections this strategy of comparison is applied in a slightly modified form to the countries of the world, which are divided into four groups. Of two dividing lines, one is between island states and other states, 'island' being defined as a sub-continental land area surrounded by water (Glassner, 1990: 47), and "island states" being defined as states that are islands or parts of an island or consist of islands and parts of islands (Anckar, 1996: 702). The other dividing line is between microstates and other states, the ceiling being one million inhabitants. Of altogether 193 states, 49 are island states; of these 30 are microstates. Of the remaining 144 states, 13 are microstates. The distribution is thus quite uneven, the vast majority of island states being small, and the vast majority of non-island states being larger than small. This unevenness is to be expected and is in the nature of things, but it also gives cause for some analytical interventions. First, the number of mainland microstates being quite small, comparisons of this group with a voluminous group of larger mainlands becomes disproportionate and in fact rather meaningless. An evaluation of the impact of size is therefore reduced to comparing small and larger islands. Second, the selection of a particular point along a continuum to dichotomize may sometimes bias findings, as dichotomization tends to lump together cases that may be extremely dissimilar (Peters, 1998: 169). This shortcoming is evident in the present materials, as a dichotomization refers fairly small islands like Jamaica, Mauritius and Trinidad \& Tobago in the group of larger island states along with, e.g., Australia, Indonesia, and United Kingdom. To correct for this, and deviating at this point from the one million ceiling, Jamaica, Mauritius and Trinidad \& Tobago are classified in the following as island microstates.

The comparative strategy is further explained in Table 2. As evident from this table, for each of the evaluated political institutions, a series of 4 comparisons are conducted. 
The first comparison is between small island states on the one hand, and all other states on the other. The meaning of this first comparison is simply to find out if and to what extent the small island states stand out as a specific group in terms of the institution at hand. Given the existence of a noteworthy difference, the subsequent comparisons aim at understanding this difference by reference to size and islandness.

The second comparison is between microstate islands and larger islands, noteworthy differences, then, islandness being controlled for, reflecting an impact of size.

The third comparison is between microstate islands and microstate mainlands, noteworthy differences, then, size being controlled for, reflecting an impact of islandness.

Finally, the fourth comparison repeats the third comparison, but now on a larger scale. Island states, regardless of size, are now compared to mainland states, regardless of size. Noteworthy differences, then, again reflect an impact of islandness.

Concerning political institutions, two sets of comparisons are carried out. A first set of three comparisons aim at elucidating the potential link between islandness and basic political system characteristics. First, the extent to which islandness relates to democracy is examined by establishing the number of democratic states in each of the four state groups. To determine democratic status, use is made of the Freedom House ratings from 1999 of the countries in the world (Karatnycky, 2000); in accordance with common practice (e.g. Diamond, 1996; Lijphart, 1999), countries that are ranked as "Free" are regarded as democracies. Second, the possible impact of the island factor on regime choice is investigated, the relevant measure being the amount of parliamentary regimes in the four groups of states. Microstate data are from a recent regime study by the present author (Anckar, 2004b), and data for other states are compiled from information in the well-known political systems encyclopedia by Derbyshire \& Derbyshire (1999). Third, to investigate the dependence of power devolution patterns on islandness, the introduction in the states of devices for decentralization is established. For the microstate group, data are from a recent study by the present author (Anckar, 2005). For larger states, data are compiled from the listings of federal states and unitary states with decentralized features in the aforementioned encyclopedia (Derbyshire \& Derbyshire, 1999: 19-23).

A second set of four comparisons are about specific institutions and devices that relate to the allimportant linkages in political life between those who represent and those who are represented. First, the methods used in national parliamentary elections (lower house) are investigated to clarify the amount of states that resort to plurality or majority elections. Concerning microstates, data are from a study by the present author (Anckar, 2002); concerning other states data are from a world-wide study by Blais and Massicotte (1997). Second, to grasp the impact of the island factor on parliamentary structure, the occurrence of bicameral legislatures is mapped for the four groups of states. Again, microstate data are from a study by the present author (Anckar, 1998), and data for other states are from the relevant listings in the Derbyshire encyclopedia (1999: 7072). Third, triangulating the study of island impact on parliamentary structure, occurrences of assembly quotas is mapped. This term stands for the method of reserving a certain number of the lower house parliamentary seats for designated groups, organizations or interests, these reserved seats often being filled by methods that are different from the method that is used in the national 
election. Concerning microstates, data are from a study by the present author, now in print (Anckar, 2006). For larger states corresponding data are not available, and are substituted by data from an unfinished study by the present author, dealing with institutional patterns and choices in all the 85 states that had democratic regimes in the year 1999. Finally, the extent to which direct democracy devices are applied in the four groups of states is investigated, microstate data being from a recent study by the present author (Anckar, 2004a) and data for other states again stemming from the study of the 1999 democracies that was mentioned above. Concerning especially the spread of constitutional referenda, a special report on that topic is consulted (Anckar \& Karvonen, 2002).

\section{Table 2: A Set of Research Questions with Attendant Comparisons.}

\begin{tabular}{|l|l|}
\hline Research Question & Form of Comparison \\
\hline Are small island states different? & $\begin{array}{l}\text { Comparison 1: } \\
\text { Compare small island states to all other } \\
\text { states }\end{array}$ \\
\hline If so, is this because small island states are small? & $\begin{array}{l}\text { Comparison 2: } \\
\text { Compare small and larger island states }\end{array}$ \\
\hline If not so, is the difference because small island states are islands? & $\begin{array}{l}\text { Comparison 3: } \\
\text { Compare small island states to small } \\
\text { mainland states }\end{array}$ \\
\hline
\end{tabular}

\section{Findings and Discussion}

Findings are reported in two tables below. Table 3 provides an overview, reporting for each institution and for each of the four comparison points (small island states versus all other states, small island states versus larger island states, small island states versus small mainland states, island states versus mainland states) the percentage of countries in each category that maintain the institutional form in question. The actual number of states is likewise reported, and as evident from the figures, the percentages are not always computed from the same amount of countries. Three of the institutions are directly or indirectly about legislatures (elections, bicameralism, assembly quotas); in consequence, countries that do not have assemblies or have suspended assembles are left out from consideration. This applies in the island microstates camp to Bahrain (Lawson, 1989) and Brunei (Saunders, 1994), in the non-island microstate camp to Qatar (Lawson, 1999: 919-20) and Vatican City (Duursma, 1994: 413-66), and in the large group of mainland states to several more countries, especially in regard to elections. As percentages are computed in the various groups from very different actual numbers, caution must be used in any interpretation, and differences between groups must be conspicuous to merit attention. Table 4, on the other hand, provides an impressionistic summation of some considerations that emanate from the figures in the previous table. From this summation, in turn, originate six general observations. 
Table 3. Political Institutions in Small Island States and in other States. Per cent Measures of the actual Number $(\mathrm{N})$ of States in each Category that maintain the Institutional Form in question.

\begin{tabular}{lcccc} 
& \multicolumn{4}{c}{ Comparison } \\
Democracy & $\mathbf{1}$ & $\mathbf{2}$ & $\mathbf{3}$ & $\mathbf{4}$ \\
$\mathrm{N}=$ & $\mathbf{7 6 - 3 7}$ & $\mathbf{7 6 - 5 6}$ & $\mathbf{7 6 - 4 6}$ & $\mathbf{6 9 - 3 5}$ \\
& $33-160$ & $33-16$ & $33-13$ & $49-144$ \\
Parliamentarism & $\mathbf{5 8 - 2 4}$ & $\mathbf{5 8 - 5 0}$ & $\mathbf{5 8 - 4 6}$ & $\mathbf{5 5 - 2 1}$ \\
$\mathrm{N}=$ & $33-160$ & $33-16$ & $33-13$ & $\mathbf{4 9 - 1 4 4}$ \\
& & & & \\
Decentralization & $\mathbf{3 0 - 3 1}$ & $\mathbf{3 0 - 5 6}$ & $\mathbf{3 0 - 8}$ & $\mathbf{3 9 - 2 8}$ \\
$\mathrm{N}=$ & $33-160$ & $33-16$ & $33-13$ & $49-144$ \\
& & & & \\
Plurality Elections & $\mathbf{8 1 - 4 1}$ & $\mathbf{8 1 - 5 6}$ & $\mathbf{8 1 - 2 7}$ & $\mathbf{7 2 - 3 9}$ \\
$\mathrm{N}=$ & $31-149$ & $31-16$ & $31-11$ & $\mathbf{4 7 - 1 3 3}$ \\
& & & & \\
Bicameralism & $\mathbf{3 2 - 3 4}$ & $\mathbf{3 2 - 5 6}$ & $\mathbf{3 2 - 1 8}$ & $\mathbf{4 0 - 4 0}$ \\
$\mathrm{N}=$ & $31-163$ & $31-16$ & $31-11$ & $\mathbf{4 7 - 1 3 9}$ \\
& & & & \\
Assembly Quotas & $\mathbf{4 2 - 3 4}$ & $\mathbf{4 2 - 3 8}$ & $\mathbf{4 2 - 3 6}$ & $\mathbf{4 0 - 2 8}$ \\
$\mathrm{N}=$ & $31-63$ & $31-16$ & $31-11$ & $\mathbf{4 7 - 5 1}$ \\
& & & & \\
Direct Democracy & $\mathbf{7 0 - 3 8}$ & $\mathbf{7 0 - 5 0}$ & $\mathbf{7 0 - 6 2}$ & $\mathbf{6 3 - 3 2}$ \\
$\mathrm{N}=$ & $33-63$ & $33-16$ & $33-13$ & $\mathbf{4 9 - 5 1}$
\end{tabular}

Key: 1 - small island states versus all other states; 2 - small island states versus larger island states; 3 - small island states versus small mainland states; 4 - island states versus mainland states.

Guide to reading the table figures: Concerning democracy, as for comparison 1 (small island states versus all other states), whereas $76 \%$ of the 33 small island states of the world are democratic, the same is true for $37 \%$ of the 160 other states. The difference is large enough to merit the conclusion that, more than other states, small island states have a democratic bent. As for comparison 4 (island states versus mainland states), the finding is that $69 \%$ of the altogether 49 island states of the world are democratic, whereas the same is true of $35 \%$ of the 144 mainland states. Again, the difference is evident enough to sustain the notion of a link between islandness and democracy.

\section{Six Observations}

(1) Small island states make a difference and they do not. In regard to some institutions, notably decentralization and bicameralism, small island states do not have a profile of their own. In regard 
to some other institutions, the situation is reversed. When compared to a set that consists of all other states in the world, the small island states are, as evident also from other pieces of research (Ott, 2000: 127-129; Srebrnik, 2004: 331-332), clearly more democratic, they adhere more firmly to the principle of parliamentarism, they are also clearly more firm supporters of plurality elections and direct democracy devices. The assembly quota institution appears to be in a sort of twilight zone between devices that are sensitive to a combination of smallness and islandness and devices that are not: small island states more than other states, and island states more than mainland states have this device, but the differences, although noticeable, are still less than dramatic. In sum, therefore, the combination of smallness and islandness that finds expression in the category of small island states goes hand in hand with some institutional choices, but not with all. Political scientists are well advised to include in their analyses islandness among the factors that shape institutional choices, but need also to be attentive to the somewhat changeable relevance of this factor.

Table 4: Research Findings: A Summary

\begin{tabular}{|l|c|c|c|}
\hline & $\begin{array}{c}\text { Are small island states } \\
\text { different? }\end{array}$ & $\begin{array}{c}\text { Because they are } \\
\text { small? }\end{array}$ & $\begin{array}{c}\text { Because they are } \\
\text { islands? }\end{array}$ \\
\hline Democracy & yes & yes, partly & yes, definitely \\
Parliamentarism & yes & no & yes \\
Decentralization & no & no & no \\
Plurality Elections & yes & yes, partly & yes, definitely \\
Bicameralism & no & no & no \\
Assembly Quotas & not really & no & no \\
Direct Democracy & yes & yes & yes \\
\hline
\end{tabular}

(2) This research departed from an ambition to find out if small island states are different because they are small or because they are islands. Looking now at the figures for those institutions in regard to which small islands really are different, the verdict is that islandness apparently contributes more than size. More often than not, the comparisons between island categories and mainland categories display larger differences than the comparison between small and larger islands. However, the differences are not always decisive, and there are, as evident also from the discussion in the next passage, several noteworthy differences between small and larger islands. On the whole, therefore, the configurations remain hazy and hard to interpret. Small size and islandness appear intertwined in terms of impact and causation, and can be separated from each other as analytical categories only with great difficulty. This somewhat impenetrable pattern certainly agrees with the much-quoted observation by Newitt that "Not all small states are islands and not all island states are small; but the problem of 'smallness' is given an added dimension in the case of an island, and insular isolation can be considerably intensified if you are also small” (1992: 16).

(3) Depending on perspectives, islands may be dealt with as a category that is distinct from other categories, or islands may be depicted and analyzed as units that are in important respects different from each other. The first perspective is evident, for instance, in the observation that the movement of peoples within and between islands has in the twentieth century increased in 
distance and become more complex in pattern and purpose, these changes incorporating islands and islanders into transnational contexts (Connell \& King, 1999: 5). The second perspective finds expression, for instance, in the placing of islands in separate categories on account of their size and their location on the main oceanic routes (Chandra, 1993: 9). Within the frame of this article the question arises to what extent between-island differences in size carry consequences for the choice of political institutions, and the findings suggest that size differences indeed penetrate the covering veil of islandness and that both perspectives therefore are relevant. Evidently, small size adds something to the general impact of islandness: whereas islands are in general more prone than mainlands to the maintenance of democracy, plurality elections and direct democracy, small islands are more consistent than larger islands in the pursuit of these policy choices. In like manner, a larger size evidently in some respects adds something to islandness. Whereas islands are no less dissociated than mainlands from bicameralism and decentralization devices, more than small islands, larger islands have introduced and nourished such institutions.

(4) The small island states are in fact an even more interesting group than suggested by a quick glance at Table 4. Not only do they in several respects represent deviation from other states; they also represent non-deviation in cases where differences could reasonably have been expected. For one thing, given the popular belief that the small size of the national polity favours centralization (Dahl \& Tufte, 1973: 36-40; Paddison, 1983: 43-44), one would certainly expect the small states to engage in decentralization policy to a much lesser extent than larger states. Still, the small islands are no different than the rest. Also, one would certainly expect that unicameral assemblies are more streamlined and effective than bicameral ones in terms of responding to the needs of small societies (Heywood, 1997: 301). Still, small island states maintain bicameral structures to about the same extent as states in general. Again, islandness obviously contributes much to this choice by small units of devices that would come more naturally to larger units. True, as was pointed out in the preceding passage, an impact also of size is discernible in larger islands maintaining more than small islands devices for decentralization and bicameralism. This impact is, however, clearly counterbalanced by the corresponding and even more obvious impact of the islandness factor. As evident from the figures, small states that engage in devices for decentralization and in bicameralism are insular units, not mainland units.

(5) Surveying the status and the achievements of the field of island studies, Baldacchino establishes a methodological rule, according to which "islandness is an intervening variable that does not determine, but contours and conditions physical and social events in distinct, and distinctly relevant ways" (2004: 278). This is no doubt a sound rule, the implication of which is that relations between independent and dependent variables need to be investigated in comparative island studies separately for island units and mainland units. However, a rule or conception that depicts islandness as an independent rather than intervening variable appears equally justified. Such a conception reflects some of the findings in this article and is also much in line with a general requirement in the methodological literature for non-obvious explanations. In a search for causes, precisely because of their proximity, factors that are close to an effect are not really satisfying as causes. Instead, a relevant search needs to be for causes that are more ultimate or fundamental. Structural variables that impact policy or behavior are illustrative examples of such more fundamental causes (Gerring, 2005: 175-176), and islandness is no doubt such a structural factor, the relevance of which is less than obvious but still promising. To the empirical justifications that have been mentioned in this article for including the islandness factor in 
analyses of institutions should therefore be added a methodological justification that stresses the priority and independence of islandness as a cause.

(6) Any causal argument presupposes a causal mechanism, i.e. a mechanism that connects cause and effect. Admittedly, the distinction between a cause and a mechanism is not always clear and unequivocal, as illustrated, for example, by the conflicting although not mutually exclusive views of islandness as an independent or an intervening variable that were given in the preceding passage. Anyhow, the link between islandness and certain political institutions brings up the question what mechanism or mechanisms support this link, and several conceivable possibilities are at hand. These have not been considered in this article and cannot be discussed here at length. Let it be said, however, that the working out and testing of mechanisms in the terrain between geography and politics remains a fascinating as well as challenging and much neglected task for the political science discipline (e.g. Gottmann, 1980: 432-433). A word of warning needs, however, to be inserted here. Among linking factors colonial heritage no doubt appears important (Ott, 2000: 69-70; Srebrnik, 2004: 333-334), and it has indeed been demonstrated in research, for instance, that the predilection of small states for plurality elections is a consequence of diffusion, the great majority of former British and American small colonies opting for plurality, and the great majority of other small colonies opting for proportionality (Anckar, 2002: 10-13). However, one should in general take care not to leap without reflection at colonial history as a valid intermediate factor. For instance, a close analysis of the regime choices of microstates reveals that the rather obvious difference in terms of democracy performance between a British and a nonBritish group is largely caused by geography differences rather than heritage differences (Anckar, 2004b: 217-220). There is much truth to the statement that the small island countries are "a welcome antidote and contrast to the anarchy, autocracy, internal warfare, militarism, violence and state collapse which is a feature of all too many larger, mainland states" (Srebrnik, 2004: 339), but our knowledge about the causes and mechanisms of this state of affairs still remains scarce and imperfect.

\section{References}

Anckar, D. (1996) 'Noncontiguity and Political Architecture: The Parliaments of Small Island States’, Political Geography, Vol. 15, No. 8, pp. 697-713.

Anckar, D. (1998) 'Bicameral Microstates: A Commonwealth Category', The Round Table, No. 347, pp. 367-378.

Anckar, D. (2002) 'Valsystem i lilleputtar: pluralitet och diffusion’, Politiikka, Vol. 44, No. 1, pp. 4-16.

Anckar, D. (2004a) 'Direct Democracy in Microstates and Small Island States', World Development, Vol. 32, No. 2, pp. 379-390.

Anckar, D. (2004b) 'Regime Choices in Microstates: The Cultural Constraint', Journal of Commonwealth \& Comparative Politics, Vol. 42, No. 2, pp. 206-223. 


\section{Anckar}

Anckar, D. (2005) 'Decentralization and Island Nationalism in Microstates: Where, How and Why?’, Canadian Review of Studies in Nationalism, Vol. 32, Nos. 1-2, pp. 109-120.

Anckar, D. (2006) 'Assembly Quotas in Microstates', Parliaments, Estates and Representation (forthcoming, 2006).

Anckar, D. \& Anckar, C. (1995) 'Size, Insularity and Democracy', Scandinavian Political Studies, Vol. 18, No. 4, pp. 211-229.

Anckar, D. \& Karvonen, L. (2002) 'Constitutional Amendment Methods in the Democracies of the World’, paper presented to the Nordic Political Science Congress, Aalborg, Denmark, August.

Baldacchino, G. (2000) 'The Challenge of Hypothermia’, The Round Table, Issue 353, pp. 65-79.

Baldacchino, G. (2002) 'Jurisdictional Self-Reliance for Small Island Territories', The Round Table, Issue 365, 349-360.

Baldacchino, G. (2004) 'The Coming of Age of Island Studies', Tijdschrift voor Economische en Sociale Geografie, Vol. 95, No. 3, pp. 272-283.

Bayliss-Smith, T.P., Bedford, R., Brookfield, H. \& Latham, M. (1988) Islands, Islanders and the World, Cambridge, Cambridge University Press.

Blais, A. \& Massicotte, L. (1997) 'Electoral Formulas: A Macroscopic Perspective', European Journal of Political Research, Vol. 32, No. 1, pp. 107-129.

Chandra, S. (1993) 'Introduction’ in S. Chandra, B. Arunachalam \& V. Suryanarayan, eds., The Indian Ocean and Its Islands, New Delhi, Sage, pp. 9-27.

Connell, J. \& King, R. (1999) 'Island Migration in a Changing World' in R. King \& J. Connell, eds., Small Worlds, Global Lives. Islands and Migration, London, Pinter, pp. 1-26.

Dahl, R.A. \& Tufte, E.R. (1973) Size and Democracy, Stanford CA, Stanford University Press.

Derbyshire, J.D. \& Derbyshire, I.D. (1999) Political Systems of the World, Oxford, Helicon Publishing.

Diamond, L. (1996) 'Is the Third Wave Over?’, Journal of Democracy, Vol. 7, No. 1, pp. 20-37.

Duursma, J. (1994) Self-Determination, Statehood and International Relations of Micro-States, Leiden, University of Leiden.

Gerring, J. (2005) 'A Unified Framework for the Social Sciences', Journal of Theoretical Politics, Vol. 17, No. 2, pp. 163-198. 
Ghai, Y. (1988) 'Constitution Making and Decolonization', in Y. Ghai, ed., Law, Politics and Government in the Pacific Island States, Suva, Institute of Pacific Studies, University of the South Pacific, pp. 1-53.

Glassner, M.I. (1990) Neptune’s Domain: A Political Geography of the Sea, London, Unwin Hyman.

Gottmann, J. (1980) 'Spatial Partitioning and the Politician’s Wisdom', International Political Science Review, Vol. 4, No. 1, pp. 432-445.

Hadenius, A. (1992) Democracy and Development, Cambridge, Cambridge University Press.

Heywood, A. (1997) Politics, London, Macmillan.

Karatnycky, A. (2000) 'A Century of Progress’, Journal of Democracy, Vol. 11, No. 1, pp. 187200.

Larmour, P. (1994) 'Is There a “New” Politics in the South Pacific?' in R. Crocombe \& W. von Busch, eds., New Politics in the South Pacific, Rarotonga and Suva, Institute of Pacific Studies, University of the South Pacific, pp. 3-15.

Lawson, F.H. (1989) Bahrain: The Modernization of Autocracy, Boulder CO, Westview Press.

Lawson, F.H. (1999) 'State of Qatar' in D.A. Kaple, ed., World Encyclopedia of Political Systems and Parties, Vol. 3, Third ed., New York, Facts on File, pp. 919-920.

Lawson, S. (1996) Tradition versus Democracy in the South Pacific: Fiji, Tonga and Western Samoa, Cambridge, Cambridge University Press.

Lijphart, A. (1999) Patterns of Democracy. Government Forms and Performance in Thirty-Six Countries, New Haven and London, Yale University Press.

Lowenthal, D. (1992) 'Small Tropical Islands: A General Overview’ in H.M. Hintjens \& M.D.D. Newitt, eds., The Political Economy of Small Tropical Islands, Exeter, University of Exeter Press, pp. 19-29.

Newitt, M. (1992) 'Introduction’ in H.M. Hintjens \& M.D.D. Newitt, eds., The Political Economy of Small Tropical Islands, Exeter, University of Exeter Press, pp. 1-17.

Ott, D. (2000) Small is Democratic: An Examination of State Size and Democratic Development, New York, Garland.

Paddison, R. (1983) The Fragmented State, Oxford, Basil Blackwell.

Peters, B.G. (1998) Comparative Politics. Theory and Methods, London, Macmillan. 


\section{Anckar}

Royle, S.A. (2001) A Geography of Islands. Small Island Insularity, London, Routledge.

Saunders, G. (1994) A History of Brunei, New York, Oxford University Press.

Srebrnik, H. (2004) 'Small Island Nations and Democratic Values', World Development, Vol. 32, No. 2, pp. 329-341. 